above $75^{\circ}$, or belonging to the mesaticephalic class, and II below $75^{\circ} \mathrm{O}$, or dolichocephaiic. The average altitudinal index is below that of the latitudinal, viz., 73. I. The average crminal capacity of the males is 1,454 cubic centimetres. They are almost as orthornathous as Europeins, and have tceth of the same comparatively small size, the dental index being in 7 male skulls 40.8 , and in 8 females $41^{\circ} 2$. The nasal index of 81 measured by I3roca was $47: S S$, and this was found to be tolcrably constant in mummies of different historical periods. The average nasal index of 25 in the College collection is rather higher, viz., $48 \%$. The orbital index of the same crania is $86 \cdot 2$. Of modern Copts unfortunately but few crania have been hitherto available for examination; but Broca gives the latitudinal index of 12 at $76^{\circ} 39$, and the nasal inclex at $47 \cdot 15$.

The cranial and other characters of the Egyptians correspond in the main with those of the Berbers and other inhabitants of North $\Lambda$ frica, and they must be placed in the same general category in any classification of the human race founded on anatomical characters. They have no affinities with the negroes, except such as may easily be accounted for by the cccasional admixture of negro blood. Indeed it is almost remarkable that there arc not more signs of this having taken place. Some authors have supposed a Turanian origin for the Egyptians, but if this term is to be taken in any sense as equivalent to Mongolians, there is absolutcly no support for it in their ostcological characters; all the characteristics of the Mongolian races are entirely absent in the Egyptian skull. Still less can any resemblance be seen to the Australian, whose skull, compared with that of an Egyptian, presents almost as great a contrast as can be found within the limits of variation of the human cranium. The angular form, limited capacity, wide zygomata, projecting supraorbital ridges, short flattened nasals, wide nasal aperture with rounded inferior border, great alveolar prognathism, retreating chin, and immonse teeth, characteristic of the Australian, are all wanting in the Egryptian. In fact the Egyptian belongs by all his anatomical characters to the type called by Blumenbach Caucasian. The much vexed questions, Who were the Egyptians? and Where did they come from? receive no answer from anatomical investigations, beyond the very simple one that they are onc of scveral modifications of the great group of races which inhabit all the lands surrounding the Mediterranean Sea; that they here lived in their own land far beyond all periods of time measured by historical events, and that in all probability it was there that they gradually developed that marvellous civilisation which has excrcised such a powerful influence over the arts, the sciences, and the religion of the whole of the Western world.

\section{THE UNITED STATES WEATHER MAPS,} SEPTEMBER, IST7

If Canada and the United States during September, 1877 , atmospheric pressure was everywhere above the normal except over a small triangrular patch bounded by the Gulf of lindy, Chesapeake Bay, and the entrance to Lake Superior. The deficiency was greatest in the North-Western States from Leavenworth to I alke Winnipeg, where it amounted to nearly the tenth of an inch, and on the consts of the Gulf of Mcxico, the deficiency at Alobile being $0^{\circ} 074$ inch. Presiure was also under the normal over Greenland, the Atlantic, the Spanish Peninsula, Italy, nearly all Austria and Prussia, the whole of Russia and Siberia, except a patch stretching in a N.N.E. and S.S.IV. direction about Lake Baikal. The centres of greatest depression were in the Atlantic between Greenland and the Azores, over a rather broad region extending castwards from Moscow to the $\mathrm{Obi}$, and from Pekin northwards to Nertschinsk, the greatest depressions below the normals of these regions for September being respectively $0^{\circ} \mathrm{I} 2 \mathrm{2}$ inch, $0^{\prime} \mathrm{I} 30 \mathrm{inch}$, and $0.05 \mathrm{I}$ inch.

Pressures were above the normal over the whole of North-Westcrn Europe, including Iceland, Sweden, Norway, Denmark, the Netherlands, France, and Germany as far as Pressburg, the greatest excess, 0.303 inch, occurring in the extreme north-west of the British Islands. But the most extensive region of unusually high pressure embraced the whole of Southern Asia, including Japan, China, except the extreme nortb, India, Syria, and al'so Egypt; and the whole of Australia, Tasmania, and New Zealand was also above the normal, and very considerably so, the excess at Deviliquin, on the Miruray River, reaching 0.265 inch.

The most remarkable disturbance in the temperature arising out of this abnormal distribution of pressure and the winds necessarily resulting therefrom, occurred over the whole of Europe, except Italy and the Spanish Peninsula. If the Weather Map be examined, it will be seen that from the west of the British Islands pressures steadily diminished on proceeding eastward over Europe, and along with this diminution of pressure pretty strong northerly winds prevailed, cxcept in the two peninsulas already referred to, where winds were southerly and the temperatures consequently above the normal. Under the influence of these northerly winds the temperature of Europe from the North Cape southwards fell greatly below the average, a deficiency of $5^{\circ} \circ$ or upwards bcing experienced at the North Cape, Christiania, Memel, Gulynki, Warsaw, and Prague. In Siberia, to the east of this cold region, southerly winds prevailed and high temperatures consequently ruled, the excess above the normal temperature being $6^{\circ} \cdot 3$ at Taschkent, $4^{\circ} \circ$ at Scmipalatinsk, and $2^{\circ} .5$ at Jenisseisk and Irkutsk. Southerly winds also prevailed over Iceland and Greenland, raising the temperature above the normal, the excess on the west of Grecnland being about $4^{\circ} \circ$, and in the northwest of Iceland $5^{\circ} \circ$. The Weather Map shows strong southerly winds also over Canada and the northern half of the United States, where consequently the temperature was high for the season, the excess being from $2^{\circ} \cdot 0$ to $3^{\circ} \circ$, rising even at some places to nearly $4^{\circ} \circ$. Further south the excess was much less; and in some cases there was cven a deficiency, as about Cape Hatteras, where northerly winds will be seen from the Map to have swept over that coast, and the tempcrature fell a degree and a half below the average; and along the upper reaches of the Arkansas and Red rivers, or to westward of the region of lowest pressure, where, winds being north-westerly, the temperature fell nearly a degree below the normal.

In India, pressure was unusually and continuously high from the beginning of the year, except in August, when it fell below the average over the region of the Lower Ganres and Assam. In September, however, pressure again became unusually high over all India, the excess being greatest along the northern coasts of the Bay of Bengal and the central districts from Visagapatam to Ajmere. In Assam the excess was considerable and the rainfall exceeded the average, whereas in Orissa, Western Bengal, and Berhar the rainfall was scanty. The excess above the normal pressure was also considerably less over Southern India and Ceylon than it was to northward; and with this distribution of the pressure occurred the memorable feature of the meteorology of India for the month, viz., an unusual strength of the south-rest monsoon over the west of India from Goa southward, accompanied with an abnormally heavy rainfall on that coast, which extended eastward over the Deccan and the greater part of the Madras Presidency, and thus terminated the disastrous famine which had wasted Mysore and a large portion of the Madras Presidency during the previous two years. 